\title{
Production and nutritional diagnosis of banana fertigated with treated sanitary wastewater ${ }^{1}$
}

\author{
Pablo Fernando Santos Alves ${ }^{2 *} \oplus$, Silvânio Rodrigues dos Santos²®, Marcos Koiti Kondo ${ }^{2} \oplus$, \\ Rodinei Facco Pegoraro ${ }^{\circledR}$, Ignacio Aspiazú2®

\footnotetext{
${ }^{1}$ Part of the first author's master's thesis in the Programa de Pós-Graduação em Produção Vegetal no Semiárido, Universidade Estadual de Montes Claros

2 Universidade Estadual de Montes Claros, Departamento de Ciências Agrárias, Janaúba, MG, Brazil. E-mail: agrotecnico10@yahoo.com.br; silvanio.santos@unimontes.br; marcos.kondo@unimontes.br; ignacio.aspiazu@unimontes.br

${ }_{3}^{3}$ Universidade Federal de Minas Gerais, Instituto de Ciências Agrárias, Montes Claros, MG, Brazil. E-mail: rodinei_pegoraro@yahoo.com.br
}

\begin{abstract}
This work evaluated the effects of the application of secondary-treatment sanitary wastewater from the Sewage Treatment Plant in Janaúba - Minas Gerais, Brazil, on the production and nutritional diagnosis of 'Prata-Anã' banana. The doses of wastewater tested were equivalent to $70,130,170$ and $200 \%$ of the $150 \mathrm{~kg} \mathrm{ha}^{-1}$ limit for sodium disposal on the soil. For comparison, a control treatment was conducted without wastewater. During two crop cycles, fruit productivity, the productivity of first- and second-class bananas, the number of hands, the number of first- and second-class hands and fruit length and diameter were determined. Banana fertigated with treated sanitary wastewater has productivity and fruits similar to those managed with mineral fertilizers and clean water. Most levels of nutrients in the leaves of 'Prata-Anã' banana are unchanged by management with treated sanitary wastewater, except for $\mathrm{Mg}, \mathrm{Fe}$, and $\mathrm{Zn}$. High leaf level of manganese in all treatments may unbalance plant nutrition, but more investigation about reference levels is necessary.
\end{abstract}

Key words: agricultural effluent reuse; environmental sanitation; Musa spp.

\section{Produção e diagnose do estado nutricional da bananeira fertirrigada com água residuária sanitária tratada}

RESUMO: O objetivo desse trabalho foi avaliar os efeitos da aplicação da água residuária sanitária de tratamento secundário da Estação de Tratamento de Esgoto de Janaúba - MG sobre a produção e a diagnose do estado nutricional da bananeira 'PrataAnã'. As doses de água residuária testadas foram equivalentes a 70,130, 170 e $200 \%$ do limite máximo de $150 \mathrm{~kg} \mathrm{ha}^{-1}$ de sódio que pode ser aportado ao solo. Para comparação, conduziu-se um tratamento testemunha sem aplicação de água residuária. Durante dois ciclos produtivos da cultura determinaram-se: produtividade total, produtividade de bananas de primeira e segunda, números de pencas total, número de pencas de primeira e segunda, comprimento e diâmetro dos frutos. A fertirrigação da bananeira com água residuária sanitária tratada propiciou produtividades e frutos com características semelhantes às plantas manejadas com fertilizantes minerais e água limpa. A maior parte dos nutrientes nas folhas da bananeira 'Prata-Anã' não é influenciada pelo manejo com água residuária sanitária tratada, com exceção do Mg, Fe e Zn. Os níveis foliares de manganês em todos os tratamentos podem comprometer o equilíbrio nutricional da bananeira, todavia, os níveis de referência para esse elemento precisam ser melhor definidos.

Palavras-chave: reuso agrícola de efluentes; saneamento ambiental; Musa spp.

\footnotetext{
* Pablo Fernando Santos Alves - E-mail: agrotecnico10@yahoo.com.br (Corresponding author)

Associate Editor: Clístenes Williams Araújo Nascimento
} 


\section{Introduction}

The use of wastewater as a partial or total source of water and nutrients in agriculture has been widely studied as an alternative to reduce production costs due to lower demand for better quality water and mineral fertilizers. Besides, it is the most rational way for disposing of these wastes, avoiding their release into watercourses and reducing their pollution potential. According to Brazil (2015), for every 1.00 USD invested in the sanitation sector, 4.00 USD are saved in the area of curative medicine in the treatment of diseases with water transmission or association. Ahmadi \& Merkley (2017) estimate that a $5 \%$ saving in irrigation consumption today can meet the demand of 4,200 people by 2030 .

Although some experimental results demonstrate the feasibility of effluent fertigation, this technique is not fully widespread in Brazil. In this context, banana cultivation constitutes an important agricultural activity in Brazil, especially in the northern region of Minas Gerais State. Brazilian production in 2016 was $6,764,585$ tons in a harvested area of 469,711 hectares. That same year, the state of Minas Gerais stood out as the third largest producer in the country, with 773,197 tons produced in 44,765 ha (IBGE, 2017). In the Northern region of Minas Gerais, the municipalities of Jaíba, Janaúba and Nova Porteirinha are the largest producers (SEAPA, 2020).

The crop is characterized by being highly demanding in terms of water and nutrients. Regarding water requirements, the application of water depths between 1,600 and 1,800 $\mathrm{mm}$ is sufficient to obtain quality fruits and good productivity (D'Albuquerque Júnior et al., 2013) and the cultivar 'PrataAnã' is one of the most efficient in water use (Santos et al., 2016). With regard to nutritional requirements, presented in decreasing order of amount absorbed, banana requires the following macronutrients: $\mathrm{K}>\mathrm{N}>\mathrm{Ca}>\mathrm{Mg}>\mathrm{S}>\mathrm{P}$; and micronutrients: $\mathrm{Cl}>\mathrm{Mn}>\mathrm{Fe}>\mathrm{Zn}>\mathrm{B}>\mathrm{Cu}$ (Borges \& Souza, 2004).

The amounts of nutrients that return to the soil (pseudostem, leaves and rhizomes) after harvest, in a banana field, are considerable and can reach approximate values of $170 \mathrm{~kg}$ of $\mathrm{N} \mathrm{ha}^{-1}$ cycle ${ }^{-1}, 9.6 \mathrm{~kg}$ of $\mathrm{P} \mathrm{ha}{ }^{-1} \mathrm{cycle}^{-1}, 311 \mathrm{~kg}^{-1} \mathrm{~K} \mathrm{ha}^{-1}$ cycle $^{-1}, 126 \mathrm{~kg}$ of Ca ha-1 cycle $^{-1}, 187 \mathrm{~kg}$ of $\mathrm{Mg} \mathrm{ha}^{-1} \mathrm{cycle}^{-1}$ and 21 $\mathrm{kg}$ of $\mathrm{S} \mathrm{ha} \mathrm{C}^{-1} \mathrm{cycle}^{-1}$, at harvest time (Borges et al., 2009). Thus, part of the nutrients absorbed by the banana are recycled during its cycle. However, in general, the soil does not have all the nutrients in the necessary amounts and availability for the plants; therefore, there is a need for mineral and, or organic fertilization.

The management of soil fertility, carried out to include unconventional sources, such as the use of treated sanitary wastewater, requires greater attention, mainly attributed to the fact that these sources are not nutritionally balanced (Alves et al., 2019) and may cause chemical changes in the soil (Sandri \& Rosa, 2017), which may compromise crop development. To detect plant responses to various types of management, leaf diagnosis of fruit plants has been used to more efficiently interpret plant nutrient relationships (Silva \& Carvalho, 2005). The Deviation from Optimum Percentage (DOP) is a method that allows knowing the percentage deviation of the concentration of any nutrient related to a value previously established and considered adequate for that nutrient in a certain phase of a crop cycle (Martinez et al., 1999).

In this context, the objective of this study was to evaluate the productivity and diagnosis of the nutritional status of the 'Prata-Anã' banana cultivar fertigated with treated sanitary wastewater.

\section{Materials and Methods}

This work was conducted in the experimental area of the Sewage Treatment Station (ETE) of the Sanitation Company of Minas Gerais (COPASA-MG) in Janaúba-MG, with the

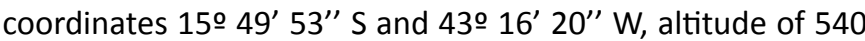
$\mathrm{m}$ and Aw (tropical, with dry winter) climate, according to Köppen.

The soil of the area where the experiment was installed is classified as Latossolo Vermelho eutrófico (Oxisol). The area showed signs of anthropogenic degradation, evidenced by the presence of poorly managed pasture and soil compaction (Table 1). Thus, subsoiling, plowing, harrowing and furrowing were performed before planting.

The treated sanitary wastewater (TWW) treatment system of the Janaúba water treatment plant is composed of preliminary treatment (grid and desander), Parshall flume with ultrasonic flowmeter, upflow anaerobic sludge blanket (UASB), facultative pond and two maturation ponds in series, with a continuous flow treatment capacity of up to $48.4 \mathrm{~L} \mathrm{~s}^{-1}$.

The design used was randomized blocks with four replicates. The treatments consisted of the application of different doses of tertiary sanitary wastewater (TWW) taking as reference the maximum annual application limit (MAL) of $150 \mathrm{~kg} \mathrm{ha}^{-1}$ of $\mathrm{Na}$ (Larcher 2006) in the soil, described as follows: T1: Control (clean water + mineral fertilization); T2: 70\%; T3: $130 \%$; T4: $170 \%$; and T5: $200 \%$ of TWW in relation to the reference MAL. After the TWW application, water supplementation was performed using clean water, both via micro-sprinkler irrigation, to meet crop requirements.

At 15 days prior to planting, basal fertilization was performed applying to the soil the formulated fertilizer NPK 4-30-10, single superphosphate and FTE BR12, aiming to supply $\mathrm{N}\left(22.8 \mathrm{~kg} \mathrm{ha}^{-1}\right), \mathrm{P}_{2} \mathrm{O}_{5}\left(200 \mathrm{~kg} \mathrm{ha}^{-1}\right), \mathrm{K}_{2} \mathrm{O}\left(50 \mathrm{~kg} \mathrm{ha}^{-1}\right), \mathrm{S}$ $\left(48.6 \mathrm{~kg} \mathrm{ha}^{-1}\right), \mathrm{Ca}\left(103.9 \mathrm{~kg} \mathrm{ha}^{-1}\right), \mathrm{B}\left(1.5 \mathrm{~kg} \mathrm{ha}^{-1}\right), \mathrm{Cu}\left(0.7 \mathrm{~kg} \mathrm{ha}^{-1}\right)$, Mn (1.7 kg ha-1), Mo (0.1 kg ha-1) and Zn (7.5 kg ha-1).

The cultivar used in the experiment was 'Prata Anã', planted on 05/05/2012, using micropropagated seedlings. The spacing used was $3 \times 2 \mathrm{~m}$, being four rows with six plants per row, totaling 24 plants per plot.

Wastewater applications started 41 days after planting (DAP), with a weekly application. From the third month after planting, chemical fertilization began, via fertigation with $\mathrm{N}$ and $\mathrm{K}$ in control and complementation in treatments 
Table 1. Soil physical and chemical attributes of the experimental area before installing the experiment.

\begin{tabular}{|c|c|c|c|c|c|c|c|c|c|c|c|}
\hline \multirow{2}{*}{$\begin{array}{l}\text { Depth } \\
\text { (m) }\end{array}$} & Ds & Dp & \multirow{2}{*}{$\begin{array}{c}\mathrm{Pt} \\
\left(\mathrm{m}^{3} \mathrm{~m}^{-3}\right)\end{array}$} & VCS & CS & MS & FS & VFS & $\begin{array}{l}\text { Total } \\
\text { sand }\end{array}$ & Silt & Clay \\
\hline & \multicolumn{2}{|c|}{$\left(\mathrm{g} \mathrm{cm}^{-3}\right)$} & & \multicolumn{8}{|c|}{$\left(\mathrm{g} \mathrm{kg}^{-1}\right)$} \\
\hline $0-20$ & 1.77 & 2.58 & 0.31 & 20 & 85 & 150 & 180 & 86 & 521 & 185 & 294 \\
\hline $20-40$ & 1.66 & 2.54 & 0.34 & 20 & 75 & 143 & 177 & 79 & 494 & 172 & 334 \\
\hline $40-60$ & 1.57 & 2.53 & 0.37 & 19 & 67 & 126 & 153 & 75 & 441 & 157 & 403 \\
\hline \multirow[t]{3}{*}{$60-80$} & 1.52 & 2.62 & 0.42 & 19 & 62 & 109 & 144 & 78 & 411 & 210 & 379 \\
\hline & $\mathrm{pH}$ & $10 M$ & $2 \mathbf{P}$ & ${ }^{2} \mathrm{~K}$ & ${ }^{2} \mathrm{Na}$ & ${ }^{3} \mathrm{Ca}$ & ${ }^{3} \mathrm{Mg}$ & ${ }^{3} \mathrm{Al}$ & ${ }^{4} \mathrm{H}+\mathrm{Al}$ & ${ }^{5} \mathrm{SB}$ & ${ }^{6} \mathrm{~T}$ \\
\hline & $\left(\mathrm{H}_{2} \mathrm{O}\right)$ & $\left(\right.$ dag kg $\left.{ }^{-1}\right)$ & \multicolumn{2}{|c|}{$\left(\mathrm{mg} \mathrm{dm}^{-3}\right)$} & \multicolumn{7}{|c|}{$\left(\mathrm{cmol}_{\mathrm{c}} \mathrm{dm}^{-3}\right)$} \\
\hline $0-20$ & 6.2 & 1.3 & 2.3 & 260 & 0.1 & 2.8 & 0.9 & 0 & 2.2 & 4.5 & 6.7 \\
\hline \multirow[t]{3}{*}{$20-40$} & 5.5 & 0.7 & 2.0 & 140 & 0.1 & 2.2 & 0.7 & 0 & 2.2 & 3.4 & 5.6 \\
\hline & $7 \mathrm{~V}$ & ${ }^{8} \mathrm{~m}$ & ${ }^{9} \mathrm{~B}$ & ${ }^{2} \mathrm{Cu}$ & ${ }^{2} \mathrm{Fe}$ & ${ }^{2} \mathrm{Mn}$ & $2 \mathrm{Zn}$ & \multirow{2}{*}{$\begin{array}{l}\text { 10P-rem } \\
\left(\mathrm{mg} \mathrm{L}^{-1}\right) \\
\end{array}$} & \multirow{2}{*}{$\begin{array}{c}{ }^{11} \mathrm{EC} \\
\left(\mathrm{dS} \mathrm{m}^{-1}\right) \\
\end{array}$} & & \\
\hline & \multicolumn{2}{|c|}{ (\%) } & \multicolumn{5}{|c|}{$\left(\mathrm{mg} \mathrm{dm}^{-3}\right)$} & & & & \\
\hline $0-20$ & 67 & 0 & 0.3 & 1.0 & 23.7 & 10.8 & 0.8 & 35.2 & 0.3 & & \\
\hline $20-40$ & 61 & 0 & 0.4 & 0.9 & 24.8 & 3.9 & 0.4 & 30.6 & 0.2 & & \\
\hline
\end{tabular}

Ds: soil density; Dp: particle density; Pt: total porosity; VCS: very coarse sand; CS: coarse sand; MS: medium sand; FS: fine sand; VFS: very fine sand; ${ }^{1}$ Organic matter, determined by colorimetry; ${ }^{2}$ Extractant: Mehlich-1; ${ }^{3}$ Extractant: $1 \mathrm{~mol} \mathrm{~L}{ }^{-1} \mathrm{KCl} ;{ }^{4} \mathrm{Estimator}$ : $\mathrm{pH} \mathrm{SMP} ;{ }^{5} \mathrm{SB}$ : sum of bases; ${ }^{6} \mathrm{~T}$ : $\mathrm{CEC}$ at $\mathrm{pH} 7 ;{ }^{7} \mathrm{~V}$ : base saturation; ${ }^{8} \mathrm{~m}$ : aluminum saturation; ${ }^{9} \mathrm{Extractant}$ : BaCl ${ }^{10}$ Remaining phosphorus, determined in equilibrium solution of $\mathrm{P} ;{ }^{11} \mathrm{EC}$ : Electrical conductivity of saturated soil extract at a ratio of 1 (soil): 0.5 (water).

with the effluent application, aiming at the balanced supply (similar doses) of these nutrients to plants of all plots. Irrigation management was based on the reference daily evapotranspiration (ETO), calculated by the PenmanMonteith method, based on data obtained from a portable weather station installed in the experimental area. The micro-sprinkler irrigation system had an application efficiency of $97 \%$, consisting of an emitter with an average flow of 76 $\mathrm{L} \mathrm{h}^{-1}$ at a working pressure of $200 \mathrm{kPa}$, with one emitter for every three plants. The other cultural practices followed the recommendations for the crop.

Monthly, during applications, simple TWW samples were collected for analysis of total $\mathrm{N}$, ammonia- $\mathrm{N}$, nitrate- $\mathrm{N}$, organic- $\mathrm{N}, \mathrm{K}, \mathrm{Na}, \mathrm{P}, \mathrm{Zn}, \mathrm{CU}, \mathrm{Fe}, \mathrm{Mn}, \mathrm{B}, \mathrm{Cl}, \mathrm{Co}, \mathrm{Ca}, \mathrm{Mg}$, electrical conductivity, chemical oxygen demand, biochemical oxygen demand, oils and greases, total suspended solids, total coliforms and Escherichia coli, following methods described in APHA et al. (2012). With the results of the previous month's TWW analyses, the fertigation depths with the TWW were calculated for the respective treatments. Table 2 shows the average chemical composition of the main constituents of wastewater during the period of the experiment.

The contribution of the main constituents of wastewater and nutrients to the soil via fertigation during the first and second years of the experiment, as well as the total applied depths, can be seen in Tables 3 and 4.

During the harvest periods in the first and second cycles, the total productivity (PROD) and the productivity of first (PROD1) and second (PROD2) categories were evaluated. The total number of hands per bunch (TNHB), number of hands of first (NH1) and second (NH2) class, fruit length (FL) and fruit diameter (FD) were also counted. The criteria for defining first- and second-class bananas followed the standards set by PBMH \& PIF (2006).

For the diagnosis of nutritional status, in the first cycle of the crop, $15 \mathrm{~cm}$ from the median inner leaf blade on the third leaf were collected, at the stage in which the inflorescence
Table 2. Average characteristics of treated sanitary wastewater from June 2012 to June 2014.

\begin{tabular}{|c|c|c|c|}
\hline Characteristics & Unit & Average & $\begin{array}{l}\text { Standard } \\
\text { deviation }\end{array}$ \\
\hline $\mathrm{N}_{\text {total }}$ & $\mathrm{mg} \mathrm{L}^{-1}$ & 47.6 & \pm 8.636 \\
\hline$N_{\text {ammon }}$ & $\mathrm{mg} \mathrm{L}^{-1}$ & 35.7 & \pm 9.66 \\
\hline $\mathrm{N}_{\text {nit }}$ & $\mathrm{mg} \mathrm{L}^{-1}$ & 1.08 & \pm 1.72 \\
\hline Norg & $\mathrm{mg} \mathrm{L}^{-1}$ & 10.82 & \pm 8.09 \\
\hline $\mathrm{K}$ & $\mathrm{mg} \mathrm{L}^{-1}$ & 33.94 & \pm 11.15 \\
\hline $\mathrm{Na}$ & $\mathrm{mg} \mathrm{L}^{-1}$ & 84.37 & \pm 19.46 \\
\hline$P$ & $\mathrm{mg} \mathrm{L}^{-1}$ & 8.22 & \pm 1.64 \\
\hline $\mathrm{Zn}^{*}$ & $m g L^{-1}$ & 0.09 & \pm 0.06 \\
\hline $\mathrm{Cu}$ & $\mathrm{mg} \mathrm{L}^{-1}$ & 0.008 & \pm 0.001 \\
\hline $\mathrm{Fe}$ & $\mathrm{mg} \mathrm{L}^{-1}$ & 0.68 & \pm 0.29 \\
\hline $\mathrm{Mn}$ & $\mathrm{mg} \mathrm{L}^{-1}$ & 0.1 & \pm 0.01 \\
\hline B & $\mathrm{mg} \mathrm{L}^{-1}$ & 0.023 & \pm 0.008 \\
\hline $\mathrm{Cl}^{-}$ & $m g L^{-1}$ & 130.6 & \pm 28.25 \\
\hline Co & $\mathrm{mg} \mathrm{L}^{-1}$ & 0.001 & \pm 0.0086 \\
\hline $\mathrm{Ca}$ & $m g L^{-1}$ & 19.13 & \pm 4.91 \\
\hline $\mathrm{Mg}^{*}$ & $m g L^{-1}$ & 7.96 & \pm 3.78 \\
\hline EC & $\mathrm{dS} \mathrm{m}^{-1}$ & 1.128 & \pm 0.162 \\
\hline $\mathrm{COD}_{\text {total }}$ & $m g L^{-1}$ & 174.8 & \pm 35.17 \\
\hline $\mathrm{BOD}_{\text {total }}$ & $\mathrm{mg} \mathrm{L}^{-1}$ & 58.88 & \pm 16.88 \\
\hline O\&G & $\mathrm{mg} \mathrm{L}^{-1}$ & 11.0 & \pm 4.12 \\
\hline $\mathrm{pH}$ & & 7.6 & \pm 0.25 \\
\hline TSS & $m g L^{-1}$ & 70.2 & \pm 33.89 \\
\hline TC & CFU $(100 \mathrm{~mL})^{-1}$ & $5.01 \mathrm{E}+6$ & $\pm 4.32 \mathrm{E}+06$ \\
\hline E. coli & MPN $(100 \mathrm{~mL})^{-1}$ & $9.6 \mathrm{E}+03$ & $\pm 3.16 \mathrm{E}+05$ \\
\hline
\end{tabular}

$\mathrm{N}_{\text {total }}$ : total nitrogen; $\mathrm{N}_{\text {ammon }}$ : ammonia nitrogen; $\mathrm{N}_{\text {nit }}$ : nitrate nitrogen; $\mathrm{N}_{\text {org }}$ : organic nitrogen; K: potassium; Na: sodium; P: phosphorus; $\mathrm{Zn}$ : zinc; $\mathrm{Cu}$ : copper; Fe: iron; $\mathrm{Mn}$ : manganese; $\mathrm{B}$ : boron; $\mathrm{Cl}$ : chloride; $\mathrm{Co}$ : cobalt; $\mathrm{Ca}$ : calcium; $\mathrm{Mg}$ : magnesium; $\mathrm{EC}$ : electrical conductivity; $\mathrm{COD}_{\text {tat }}$ : chemical oxygen demand; $\mathrm{BOD}_{\text {tota }}$ : biochemical oxygen demand; O\&G: oils and greases; TSS: total suspended solids; TC: total coliforms; E. coli: Escherichia coli; *: Quantified only from 02/2013.

had all female hands uncovered (without bracts) (Borges \& Souza, 2004). Subsequently, the samples were placed in properly identified paper bags and then sent for laboratory analysis of $\mathrm{N}, \mathrm{P}, \mathrm{K}, \mathrm{S}, \mathrm{Ca}, \mathrm{Mg}, \mathrm{B}, \mathrm{Cu}, \mathrm{Fe}, \mathrm{Mn}, \mathrm{Zn}$, and $\mathrm{Na}$. The results obtained were compared with the critical reference levels proposed by Montañés et al. (1993).

Data were subjected to analysis of variance and, when $F$ was significant up to $5 \%$ of probability, regression analysis 
Table 3. Nutrients and $\mathrm{Na}$ added to the soil $(\mathrm{kg})$ in each treatment, in two years of cultivation of banana fertigated with treated sanitary wastewater.

\begin{tabular}{|c|c|c|c|c|c|c|c|c|c|c|c|}
\hline & \multicolumn{3}{|c|}{$\mathbf{N}_{\text {total }}$} & \multicolumn{3}{|c|}{$\mathrm{P}_{2} \mathrm{O}_{5}$} & \multicolumn{3}{|c|}{$\mathrm{K}_{2} \mathrm{O}$} & \multicolumn{2}{|c|}{$\mathrm{Na}$} \\
\hline & MF & TWW & Tot. & MF & TWW & Tot. & MF & TWW & Tot. & TWW & Tot. \\
\hline & \multicolumn{11}{|c|}{ Year 1} \\
\hline Cont. & 226.2 & 0.0 & 226.2 & 200 & 0.0 & 200 & 253.3 & 0.0 & 253.3 & 0.0 & 0.0 \\
\hline 70 & 143.3 & 86.6 & 229.9 & 200 & 27.5 & 227.5 & 198.2 & 58.1 & 256.3 & 103.8 & 103.8 \\
\hline 130 & 120.8 & 114.2 & 235.0 & 200 & 55.0 & 255.0 & 143.7 & 115.6 & 259.3 & 206.5 & 206.5 \\
\hline 170 & 109.8 & 127.6 & 237.4 & 200 & 67.8 & 267.8 & 117.2 & 142.5 & 259.7 & 255.2 & 255.2 \\
\hline \multirow[t]{2}{*}{200} & 98.5 & 141.0 & 239.5 & 200 & 81.3 & 281.3 & 90.2 & 170.3 & 260.5 & 304.8 & 304.8 \\
\hline & \multicolumn{11}{|c|}{ Year 2} \\
\hline Cont. & 320.0 & 0.0 & 320.0 & 100.0 & 0.0 & 100.0 & 320.0 & 0.0 & 320.0 & 0.0 & 0.0 \\
\hline 70 & 236.2 & 89.3 & 325.5 & 76.5 & 25.42 & 101.9 & 274.8 & 49.79 & 324.6 & 106.6 & 106.6 \\
\hline 130 & 212.5 & 114.7 & 327.2 & 55.1 & 46.27 & 101.4 & 233.4 & 91.58 & 325.0 & 196.6 & 196.6 \\
\hline 170 & 198.9 & 133.2 & 332.1 & 42.6 & 60.46 & 103.1 & 209.4 & 119.78 & 329.2 & 258.3 & 258.3 \\
\hline 200 & 187.1 & 146.1 & 333.2 & 31.8 & 71.24 & 103.0 & 188.8 & 140.75 & 329.6 & 303.7 & 303.7 \\
\hline
\end{tabular}

TWW: treated wastewater; MF: mineral fertilization; $\mathrm{N}_{\text {}}$ : total nitrogen available to the crop, $\mathrm{P}_{2} \mathrm{O}_{5}$ : phosphorus; $\mathrm{K}_{2} \mathrm{O}$ : potassium, Na: sodium; Cont.: Clean water and mineral fertilize top-dressing; 70: 70\%; 130: 130\%; 170: 170\%; 200: 200\% of the limit of addition (Larcher, 2006) of sodium in the soil via TWW (150 $\mathrm{kg} \mathrm{ha}^{-1} \mathrm{year}^{-1}$ ).

Table 4. Depths applied to the experimental plots in two years of cultivation of banana plants fertigated with treated sanitary wastewater.

\begin{tabular}{|c|c|c|c|c|c|c|c|c|}
\hline \multirow{3}{*}{ Treat. } & \multicolumn{4}{|c|}{ Year 1} & \multicolumn{4}{|c|}{ Year 2} \\
\hline & TWW & Rain & LD & Total & TWW & Rain & LD & Total \\
\hline & \multicolumn{8}{|c|}{$(\mathrm{mm})$} \\
\hline Cont. & 0 & 432.8 & 2205.2 & 2638 & 0 & 471.7 & 2010.9 & 2482.6 \\
\hline 70 & 127.1 & 432.8 & 2078.1 & 2638 & 104.14 & 471.7 & 1906.8 & 2482.6 \\
\hline 130 & 252.7 & 432.8 & 1952.5 & 2638 & 190.83 & 471.7 & 1820.1 & 2482.6 \\
\hline 170 & 312.5 & 432.8 & 1892.7 & 2638 & 251.66 & 471.7 & 1759.2 & 2482.6 \\
\hline 200 & 373.4 & 432.8 & 1831.8 & 2638 & 295.71 & 471.7 & 1715.2 & 2482.6 \\
\hline
\end{tabular}

Rain: effective precipitation; LD: complementary net irrigation depths; Total: total depths applied to the experimental plots.

was performed. For the comparison of treatment means related to control, the Dunnett's test at 5\% significance level was used.

\section{Results and Discussion}

\section{Banana productivity}

Regarding banana productivity data, in the two cycles evaluated, in general, there were no differences in the management with treated sanitary wastewater compared to the management with clean water (Table 5).

The average national banana productivity in 2017 was 14.8 $\mathrm{t} \mathrm{ha} \mathrm{H}^{-1}$, while the productivity in the state of Minas Gerais was $17.3 \mathrm{t} \mathrm{ha}^{-1}$ (IBGE, 2017). These data include many technological levels and cultivars.

Silva et al. (2007) adopt the following criteria to define productivity levels: low productivity $\left(<25 \mathrm{t} \mathrm{ha}^{-1}\right.$ year $\left.^{-1}\right)$, average productivity ( 25 to $32 \mathrm{t} \mathrm{ha}^{-1}$ year $^{-1}$ ) and high productivity (>

Table 5. Means of treatments and Dunnett's test for the productive characteristics of banana fertigated with treated sanitary wastewater in two production cycles.

\begin{tabular}{|c|c|c|c|c|c|c|c|c|}
\hline Treat. & Prod & $\begin{array}{l}\text { Prod1 } \\
\left(\text { t ha }^{-1}\right)\end{array}$ & Prod2 & TNH & NH1 & NH2 & $\begin{array}{c}\mathrm{FL} \\
(\mathrm{cm})\end{array}$ & $\begin{array}{c}\text { FD } \\
(\mathrm{mm})\end{array}$ \\
\hline \multicolumn{9}{|c|}{$1^{\text {st }}$ cycle } \\
\hline 70 & 29.31 & 18.11 & 11.64 & 9.66 & 4.91 & 4.75 & 15.28 & 39.17 \\
\hline 130 & 29.25 & 17.68 & 11.57 & 9.50 & 5.16 & 4.34 & 15.78 & 39.12 \\
\hline 170 & 29.81 & 16.41 & 13.53 & 9.47 & 4.38 & 5.09 & 15.42 & 37.98 \\
\hline 200 & 28.45 & 15.70 & 13.48 & 9.56 & 3.91 & 5.66 & 15.17 & 38.33 \\
\hline Control & 26.32 & 13.37 & 11.93 & 9.25 & 4.06 & 5.19 & 14.98 & 37.05 \\
\hline \multicolumn{9}{|c|}{$2^{\text {nd }}$ cycle } \\
\hline 70 & 38.85 & 36.28 & 2.57 & $9.91^{*}$ & 9.03 & 0.88 & 17.86 & 42.05 \\
\hline 130 & 35.11 & 33.45 & 1.62 & 9.41 & 8.78 & 0.63 & 17.89 & 42.05 \\
\hline 170 & 34.60 & 32.97 & 1.63 & 9.36 & 8.83 & 0.53 & 17.80 & 41.70 \\
\hline 200 & 39.57 & 38.47 & 1.10 & $9.81^{*}$ & 9.47 & 0.34 & 18.38 & 43.06 \\
\hline Control & 33.81 & 31.32 & 2.49 & 9.19 & 8.34 & 0.84 & 17.64 & 41.72 \\
\hline
\end{tabular}

In each production cycle, means followed by an asterisk $\left({ }^{*}\right)$ differ statistically from the control by Dunnett's test at a $5 \%$ significance level.

$\left({ }^{*}\right)$ Significant at $1 \%,(* *)$ significant at $5 \%$ and $(n s)$ non-significant by the $\mathrm{F}$ test;

PROD: total productivity, PROD1: productivity of first-class bananas, PROD2: productivity of second-class bananas, TNH: total number of hands, NH1: number of first-class hands, NH2: number of second-class hands, FL: fruit length and FD: fruit diameter. 
$32 \mathrm{t} \mathrm{ha}^{-1}$ year $\left.{ }^{-1}\right)$. These limits consider that the 'Prata-Anã' banana planted in northern Minas Gerais becomes profitable from the average productivity of $28 \mathrm{t} \mathrm{ha}^{-1}$ year $^{-1}$. Considering this information, it can be observed (Table 5 ) that the average total productivity (PROD) obtained under the conditions of this work was satisfactory since in the first crop cycle the average productivity level was already reached. In the second production cycle, the productivity numbers could be defined as high.

In the first crop cycle, although there were no significant differences, there were relative increases in total yield on the order of T2: 11.36; T3: 11.13; T4: 13.25 and T5: 8.09\%, compared to the control. For the second production cycle, these increments were: T2: 14.91; T3: 3.85; T4: 2.34 and T5: $17.04 \%$. Besides, the management with TWW in this study, considering the highest doses, provided savings of up to $56.45 \% \mathrm{~N}$ and $64.39 \% \mathrm{~K}_{2} \mathrm{O}$ in the first cycle, and $41.53 \% \mathrm{~N}$, $68.2 \% \mathrm{P}_{2} \mathrm{O}_{5}$ and $41 \% \mathrm{~K}_{2} \mathrm{O}$ in the second cycle. Similar results were obtained by Johns \& McConchie (1994), adding $600 \mathrm{~mm}$ of secondary sewage treatment effluent providing $20 \%$ of the total $\mathrm{N}$ required by the banana and producing $10 \%$ more than conventional management without causing environmental damage.

The good productivity results in this work are probably related to the correct management of the fertilization, especially regarding the wastewater management, in which the split application provides nutrients in a controlled way for the plants. Despite these results, it is emphasized that the supplementation of fertilization with industrialized mineral fertilizers, aiming to supply the nutrients in deficit in the wastewater, may also have played an important role in the occurrence of good productivities. Failure to follow this procedure could lead to unsatisfactory results, especially in the long run, due to the large amount of nutrients that are exported by the banana tree in each cycle. Another relevant fact for the occurrence of good productivities is water availability, favored by the correct irrigation management, as shown by the net depths of wastewater, clean water, and rainfall recorded in Table 4 .

Regarding the productivity of first-class bananas (PROD1) in the two evaluated cycles, as well as the total productivity data (PROD), no difference was found between treatments. However, the use of TWW as a partial source of nutrients promoted increased PROD1 values compared to clean water management, whose values were $70 \%$ TWW: $35.45 \%$; $130 \%$ TWW: $32.24 \%$, 170\% TWW: $22.74 \%$ and $200 \%$ TWW: $17.43 \%$ for the first cycle, and 70\% TWW: $15.84 \% ; 130 \%$ TWW: $6.8 \%$; 170\% TWW: $5.27 \%$ and $200 \%$ TWW: $22.83 \%$ for the second production cycle.

Thus, it is verified that these effects were characterized by the reduction of the number of first-class bananas with the increase of the TWW dose in the first cycle. Possibly, this fact is due to the non-immediate supply of the nutritional needs of the crop, given that part of the nutrients available via TWW, mainly $\mathrm{P}$ and $\mathrm{N}$, are in larger proportions in the organic form in treatments with the higher dose of TWW, requiring mineralization before their use by plants. In the second production cycle, this relationship cannot be established. According to Mantovani et al. (2006), part of organic $\mathrm{N}$ from soil-added compounds is mineralized to $\mathrm{NH}^{4+}$ and $\mathrm{NO}^{-3}$ and the other part may remain unchanged or be incorporated into soil microbial biomass, which may have happened to organic $\mathrm{N}$ and $\mathrm{P}$ supplied via TWW (Table 3 ).

The productivity ratio of first-class (PROD1) and secondclass (PROD2) bananas is of great importance in the banana production chain, as second-class bananas are traded at a lower value. Second-class fruit is generally traded at $60 \%$ of the value of a first-class fruit.

Regarding the total number of hands (TNH), it was found that the treatments $70 \%$ TWW and $200 \%$ TWW promoted the highest number of hands per plant compared to the management with clean water (Table 5). However, as the results of the number of first-class hands $(\mathrm{NH} 1)$ and the number of second-class hands (NH2), as well as PROD, PROD1 and PROD2, were not altered, the higher TNH is associated with a lower weight of the hands in the bunch. According to Borges \& Souza (2004), the occurrence of rickety bunches and a smaller number of hands are typical symptoms of $\mathrm{N}$ deficiency for the banana crop. However, considering that the other production components were not altered, the higher TNH and possibly lower weight of hands become little significant.

Fruit length (FL) and fruit diameter (FD) were not influenced by wastewater management compared to clean water management, and the results for these variables showed the lowest coefficients of variation between the evaluated characteristics.

Large amounts of sodium may impair soil fertility and plant nutrition (Silva et al., 2011). Despite these problems, the inputs of this element to the soil, which reached more than $300 \mathrm{~kg} \mathrm{ha}^{-1}$ year $^{-1}$ in this work (Table 3), did not compromise banana production and its components. However, the recommendation of doses to be used in TWW management is conditioned on further studies.

\section{Diagnosis of nutritional status}

Leaf concentration of most of the nutrients quantified in the leaves was not influenced by the treatments, except for $\mathrm{Mg}$, Fe, and Zn (Table 6).

Regarding Mg concentration in leaves, there is a $40.91 \%$ increase in bananas fertigated with $170 \%$ of TWW. According to Garcia et al. (2007), the increase of soil salinity, evidenced in their work by increasing values of electrical conductivity, reduced $\mathrm{Mg}$ levels in corn leaves at various stages of the crop cycle. Thus, considering the increasing contribution of $\mathrm{Na}$ (Table 3) due to the increase of TWW dose and considering the potential of this element to increase the values of soil electrical conductivity (Tavares Filho et al., 2012), it is believed that the increase of soil salinity may have contributed for the use of TWW at $200 \%$ not promoting the increase in $\mathrm{Mg}$ concentration in banana leaves. In addition to the role of $\mathrm{Mg}$ as a cofactor in almost all energy metabolism enzymes and 
Table 6. Means of treatments and Dunnett's test for leaf nutritional contents in banana fertigated with treated sanitary wastewater.

\begin{tabular}{|c|c|c|c|c|c|c|c|c|c|c|c|c|}
\hline \multirow{2}{*}{ Treatment } & $\mathbf{N}$ & $\mathbf{P}$ & $\mathbf{K}$ & $S$ & $\mathrm{Ca}$ & $\mathrm{Mg}$ & B & $\mathrm{Cu}$ & $\mathrm{Fe}$ & $M n$ & $\mathrm{Zn}$ & $\mathrm{Na}$ \\
\hline & \multicolumn{6}{|c|}{$\left(\right.$ dag kg $\left.^{-1}\right)$} & \multicolumn{6}{|c|}{$\left(\mathrm{mg} \mathrm{kg}^{-1}\right)$} \\
\hline 70 & 2.92 & 0.13 & 2.61 & 0.18 & 0.69 & 0.22 & 14.41 & 6.42 & 51.94 & 439.63 & 11.24 & 28.88 \\
\hline 130 & 2.89 & 0.14 & 2.94 & 0.18 & 0.75 & 0.28 & 10.63 & 6.66 & $68.32^{*}$ & 516.23 & 14.53 & 41.13 \\
\hline 200 & 2.86 & 0.14 & 2.84 & 0.19 & 0.76 & 0.29 & 9.99 & 6.78 & 64.34 & 474.81 & 14.31 & 42.88 \\
\hline Control & 2.87 & 0.13 & 2.93 & 0.20 & 0.67 & 0.22 & 11.22 & 6.36 & 54.33 & 487.17 & 12.90 & 37.38 \\
\hline
\end{tabular}

Means followed by an asterisk $\left({ }^{*}\right)$ differ from the control at a $5 \%$ level of significance by the Dunnett's test.

the chlorophyll molecule, this ion is required for ribosome integrity and effectively contributes to the structural stability of nucleic acids and membranes (Taiz \& Zeiger, 2017).

Fe concentration in banana leaves increased by $25.75 \%$ with $130 \%$ of TWW compared to the control treatment (Table 6). The average concentration of Fe in TWW from the treatment station in Janaúba during the experiment period was $0.68 \mathrm{mg} \mathrm{L}^{-1}$. Thus, it was expected that the increased input of this element would result in higher soil availability and higher plant uptake; however, this fact was not confirmed for doses above $130 \%$ of TWW. These results were possible because part of Fe transported to the soil binds to organic compounds or other minerals, forming complexes with low availability to plants (Pegoraro et al., 2006). Other factors that may have contributed for higher TWW doses not increasing Fe bioavailability would be increased salinity (Bosco et al., 2009) and soil $\mathrm{pH}$.

$\mathrm{Zn}$ leaf contents increased with the TWW dose exponentially up to a maximum of $14.7892 \mathrm{mg} \mathrm{kg}^{-1}$ (Figure 1). This increase is observed due to the higher contribution of $\mathrm{Zn}$ at the highest doses of TWW, which led to an average concentration of this element of $0.09 \mathrm{mg} \mathrm{L}^{-1}$. However, despite the observed increases in TWW management, $\mathrm{Zn}$ leaf contents did not differ from that of the control treatment. Palácios et al. (2001) also verified increases in leaf $Z n$ contents with the use of secondary effluent in banana irrigation, which

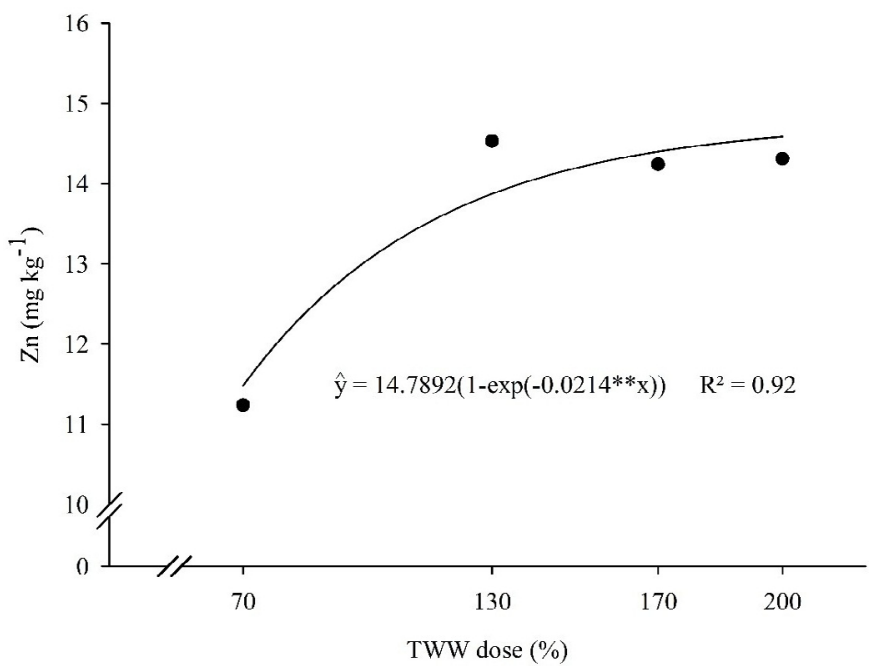

Figure 1. Concentration of $\mathrm{Zn}$ in banana leaves as a function of the application of different doses of treated sanitary wastewater in Janaúba-MG. was classified as a risk if the effluent is used for a prolonged period. For Taiz and Zeiger (2017), the main role of $Z n$ in the plant is related to enzymatic activity, with evidence that it is related to the biosynthesis of tryptophan, which is one of the precursors of natural auxin, indole-3-acetic acid (IAA). Despite the increases in leaf $\mathrm{Zn}$ levels, no phytotoxic effects were observed in the field.

Given the leaf concentrations of nutrients evaluated in this study and comparing these results (Table 7) with the reference levels proposed for banana cultivation by Martinez et al. (1999), the deviation from optimum percentage (DOP) (Montañés et al. 1993) was determined for each treatment, graphically represented by a fertigram (Figure 2).

The DOP index indicates the order of nutrient limitation. A negative index indicates deficiency; when positive, excess; and zero, optimal nutrient concentration. The higher its absolute value, the greater the severity of the shortage or excess. Thus, the fertigram allows the visual analysis of the adequacy of the concentrations of each particular nutrient and the analysis of the nutritional status of the crop as a whole (Martinez et al., 1999)

Thus, in all treatments, the nutritional balance is close to that appropriate for the crop (Figure 2), consistent with the average productivities obtained. However, the leaf contents of $\mathrm{Mn}$ deserve greater attention.

The ions $\mathrm{Mn}^{2+}$ activate some enzymes in the cell, in particular, decarboxylases and dehydrogenases involved in the Krebs cycle (respiration). However, the most well-defined function of $\mathrm{Mn}^{2+}$ is its participation in the photosynthesis reaction, in which $\mathrm{O}_{2}$ is produced from $\mathrm{H}_{2} \mathrm{O}$. When deficiencies of this nutrient occur, the most frequent symptom is an interveinal chlorosis associated with small necrotic spots that may occur in young or old leaves, depending on the plant species and growth rate (Taiz \& Zeiger 2017).

Regarding the excess of this nutrient, Veloso et al. (1995) found that increasing the concentration of $\mathrm{Mn}$ in nutrient solution reduced plant development and the absorption of $\mathrm{P}$, $\mathrm{K}, \mathrm{Ca}, \mathrm{Mg}, \mathrm{Cu}, \mathrm{Fe}$, and $\mathrm{Zn}$. According to Beyer et al. (2013), the excess of $\mathrm{Mn}$ in exchangeable and soluble forms in the growth medium increases its quantity in plant tissues, which can reach toxic levels and cause the reduction of plant biomass.

Considering that the treatments did not differ in relation to the leaf concentration of this nutrient, and the yields obtained in the first cycle were good, it is believed that the critical levels for Mn defined in Martinez et al. (1999) are 
Table 7. Critical reference level (CRL) and percentage deviation from optimum percentage (DOP) for nutritional concentrations (leaf conc.) in 'Prata-Anã' bananas fertigated with different doses of treated sanitary wastewater in Janaúba.

\begin{tabular}{cccccccccccc}
\hline \multirow{2}{*}{ Nutrient } & \multirow{2}{*}{ CRL/1 } & \multicolumn{2}{c}{ Control } & \multicolumn{2}{c}{$\mathbf{7 0}$} & \multicolumn{2}{c}{$\mathbf{1 3 0}$} & \multicolumn{2}{c}{170} & \multicolumn{2}{c}{$\mathbf{2 0 0}$} \\
\cline { 3 - 12 } & & Leaf Conc. & DOP & Leaf Conc. & DOP & Leaf Conc. & DOP & Leaf Conc. & DOP & Leaf Conc. & DOP \\
\hline $\mathrm{N}$ & 2.6 & 2.9 & 10.4 & 2.9 & 12.3 & 2.9 & 11.2 & 2.8 & 8.8 & 2.9 & 10.0 \\
$\mathrm{P}$ & 0.22 & 0.1 & -40.9 & 0.1 & -40.9 & 0.1 & -36.4 & 0.2 & -31.8 & 0.1 & -36.4 \\
$\mathrm{~K}$ & 2.8 & 2.9 & 4.6 & 2.6 & -6.8 & 2.9 & 5.0 & 2.9 & 2.5 & 2.8 & 1.4 \\
$\mathrm{~S}$ & 0.6 & 0.2 & -66.7 & 0.2 & -70.0 & 0.2 & -70.0 & 0.2 & -66.7 & 0.2 & -68.3 \\
$\mathrm{Ca}$ & 0.3 & 0.7 & 123.3 & 0.7 & 130.0 & 0.8 & 150.0 & 0.8 & 173.3 & 0.8 & 153.3 \\
$\mathrm{Mg}$ & 0.2 & 0.2 & 10.0 & 0.2 & 10.0 & 0.3 & 40.0 & 0.3 & 55.0 & 0.3 & 45.0 \\
$\mathrm{~B}$ & 15 & 11.2 & -25.2 & 14.4 & -3.9 & 10.6 & -29.1 & 12.3 & -18.1 & 10.0 & -33.4 \\
$\mathrm{Cu}$ & 8 & 6.4 & -20.5 & 6.4 & -19.8 & 6.7 & -16.8 & 6.8 & -14.5 & 6.8 & -15.3 \\
$\mathrm{Fe}$ & 100 & 54.3 & -45.7 & 51.9 & -48.1 & 68.3 & -31.7 & 62.0 & -38.0 & 64.3 & -35.7 \\
$\mathrm{Mn}$ & 8 & 487.2 & 453.6 & 439.6 & 399.6 & 516.2 & 486.6 & 485.4 & 451.6 & 474.8 & 439.6 \\
$\mathrm{Zn}$ & 20 & 12.9 & -35.5 & 11.2 & -43.8 & 14.5 & -27.4 & 14.2 & -28.8 & 14.3 & -28.5 \\
\hline
\end{tabular}

(1) Martinez et al. (1999).
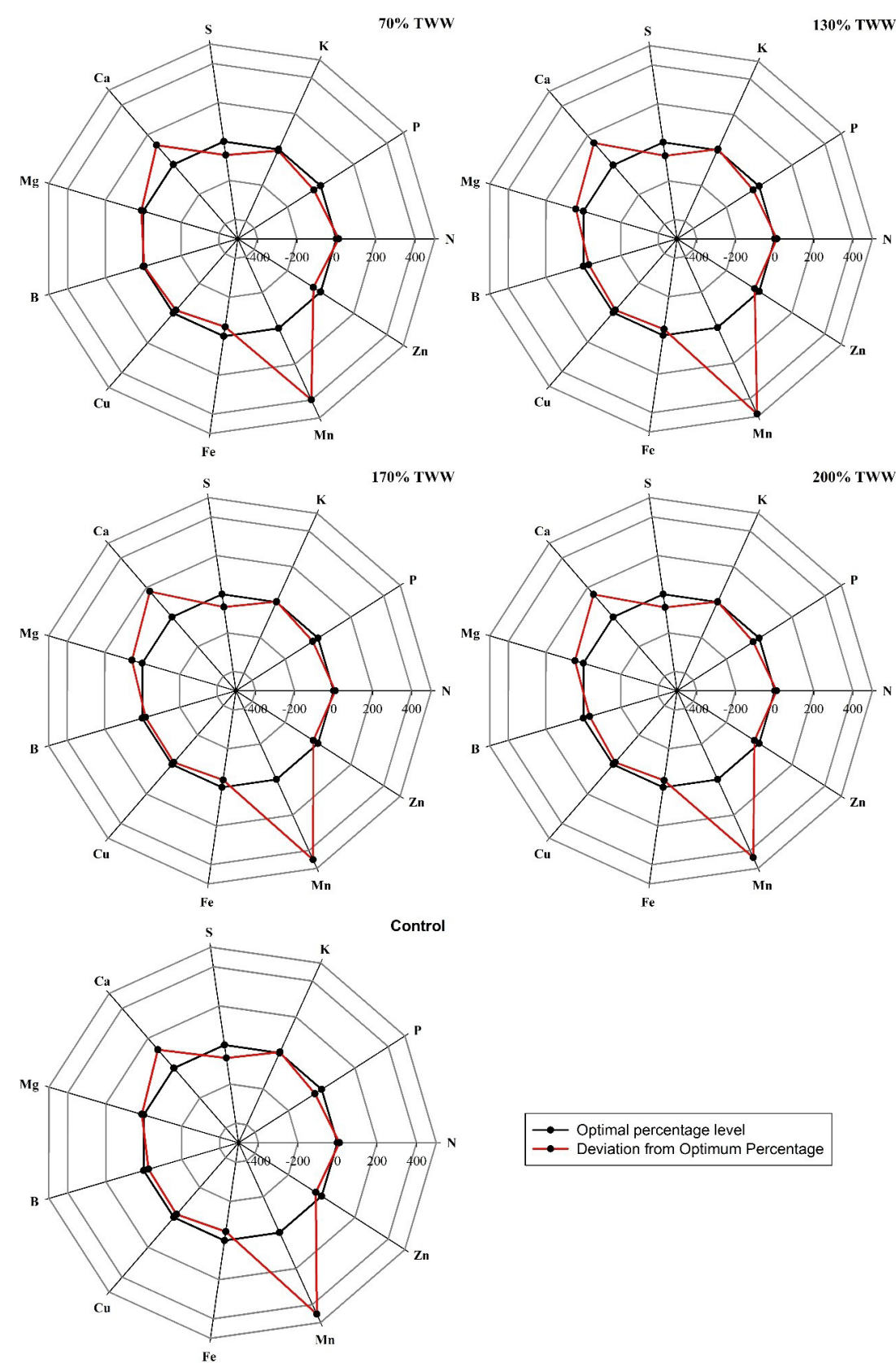

$\longrightarrow$ - Optimal percentage level
$\rightarrow$ Deviation from Optimum Percentage

Figure 2. Representative fertigram of the nutritional balance proposed by Martinez et al. (1999) in bananas fertigated with different doses of treated sanitary wastewater. Janaúba - MG. 
underestimated for the crop. Moreover, it is noteworthy that these levels were established as a reference for banana plants in general, without distinguishing between varieties, possibly contributing to misunderstandings in the interpretation of results. Borges \& Souza (2004) recommends that the adequate concentration of $\mathrm{Mn}$ in banana leaves of the cultivar 'Prata-Anã' is between 173 and 630 mg kg-1, which are more consistent with the results obtained in this work.

About leaf contents of $\mathrm{Na}$, Borges \& Oliveira (2006) report that concentrations above $300 \mathrm{mg} \mathrm{kg}^{-1}$ at the beginning of flowering and $3,500 \mathrm{mg} \mathrm{kg}^{-1}$ with the fully produced bunch are considered toxic to the banana, causing marginal blackening followed by leaf necrosis. The maximum dose of $\mathrm{Na}$ added to the soil in the first year of cultivation in this study was $304.8 \mathrm{~kg} \mathrm{ha}^{-1}$ (200\% of TWW). However, this contribution did not determine the increment of the element in the banana leaves compared to the other treatments and the control (Table 6). Palácios et al. (2001) report that banana irrigation with groundwater contributed to leaf $\mathrm{Na}$ contents similar $(\mathrm{p}<0.05)$ to irrigation with the mixture of desalinated secondary effluent ( $70 \%$ proportion) plus secondary effluent ( $30 \%$ proportion), demonstrating that the use of effluent may be a viable alternative to other sources usually used for irrigation of this crop.

\section{Conclusions}

Fertigation of banana trees with treated sanitary wastewater promotes productivities and fruits with characteristics similar to those managed with mineral fertilizers and clean water.

Most of the nutrients present in 'Prata-Anã' banana leaves are not influenced by the treatment with treated sanitary wastewater, except for $\mathrm{Mg}$, Fe, and $\mathrm{Zn}$.

The high $\mathrm{Mn}$ content may compromise the nutritional balance for the banana; however, due to the absence of phytotoxic symptoms or reduced yield, it is inferred that the range considered adequate for the crop and, or, cultivar 'Prata-Anã' must exceed current standards for the crop.

\section{Acknowledgments}

The authors would like to thank the following for their financial support: the Sanitation Company of Minas Gerais, Banco do Nordeste, Minas Gerais State Research Support Foundation (FAPEMIG), and the National Council for Scientific and Technological Development (CNPq).

This study was financed in part by the Coordenação de Aperfeiçoamento de Pessoal de Nível Superior - Brasil (CAPES) - Finance Code 001

\section{Compliance with Ethical Standards}

Funding: Companhia de Saneamento de Minas Gerais, Banco do Nordeste, Coordenação de Aperfeiçoamento de Pessoal de Nível Superior (Finance Code 001), Fundação de Amparo à Pesquisa do Estado de Minas Gerais, Universidade Estadual de Montes Claros.
Conflict of interest: The authors declare that there is no possible conflict of interest that may influence the article.

Author contribution: Conceptualization: SRS, MKK; Data curation: PFSA; Formal Analysis: PFSA; Investigation: PFSA; Methodology: PFSA, SRS, MKK; Project administration: SRS; Resources: RFP; Supervision: SRS, MKK; Visualization: PFSA, IA; Writing - review \& editing: PFSA, SRS, MKK, RFP; Writing original draft: IA.

\section{Literature Cited}

Ahmadi, L.; Merkley, G. P. Wastewater reuse potential for irrigated agriculture. Irrigation Science, v.35, n.4, p.275-285, 2017. https:// doi.org/10.1007/s00271-017-0539-7.

Alves, P. F. S.; Santos, S. R. Dos; Kondo, M. K.; Pegoraro, R. F.; Portugal, A. F. Soil chemical properties in banana crops fertigated with treated wastewater. Revista Caatinga, v.32, n.1, p.234-242, 2019. https://doi.org/10.1590/1983-21252019v32n123rc.

American Public Health Association - APHA; American Water Works Association - AWWA; Water Environment Federation - WEF. Standard methods for examination of water and wastewater. 22.ed. Washington: American Public Health Association, 2012. 1496p.

Beyer, W. N.; Green, C. E.; Beyer, M.; Chaney, R. L. Phytotoxicity of zinc and manganese to seedlings grown in soil contaminated by zinc smelting. Environmental Pollution, v.179, p.167-176, 2013. https://doi.org/10.1016/j.envpol.2013.04.013.

Borges, A. L.; Oliveira, A. M. G. Avaliação do estado nutricional da bananeira - Diagnose visual. Cruz das Almas, BA: Embrapa Mandioca e Fruticultura, 2006. 7p. (Embrapa Mandioca e Fruticultura. Comunicado técnico, 117). https://www.infoteca. cnptia.embrapa.br/infoteca/bitstream/doc/1028198/1/ ctecnico117.pdf. 11 Mar. 2020.

Borges, A. L.; Silva, A. L. da; Batista, D. da C.; Moreira, F. R. B.; Flori, J. E.; Oliveira, J. E. de M.; Araújo, J. L. P.; Pinto, J. M.; Castro, J. M. da C. e; Moura, M. S. B. de; Azoubel, P. M.; Cunha, T. J. F.; Silva, S. de O. e; Cordeiro, Z. J. M.. Sistema de produção da bananeira irrigada. Petrolina: Embrapa Semiárido, 2009. (Embrapa Semiárido. Sistemas de Produção, 4). http://ainfo. cnptia.embrapa.br/digital/bitstream/item/110622/1/Sistemade-Producao-da-Bananeira-Irrigada.pdf. 12 Mar. 2020.

Borges, A. L.; Souza, L. D. S. (Eds.). O cultivo da bananeira. 1.ed. Cruz das Almas: Embrapa Mandioca e Fruticultura, 2004. 279p. https://www.embrapa.br/en/busca-de-publicacoes/-/ publicacao/1005043/o-cultivo-da-bananeira. 17 Feb. 2020.

Bosco, M.; Oliveira, A. De; Hernandez, F.; Lacerda, C. F. De. Influência do estresse salino na composição mineral da berinjela. Revista Ciência Agronômica, v.40, n.2, p.157-164, 2009. http://www.ccarevista. ufc.br/seer/index.php/ccarevista/article/view/507. 12 Mar 2020.

Brasil. Ministério da Saúde. Fundação Nacional de Saúde. Manual de saneamento. 4ed. Brasília: Funasa, 2015. 642p.

D’Albuquerque Júnior, B. S.; Gomes, E. R.; Sousa, V. F. D.; Sousa, A. D. P. Necessidade hídrica e lâminas de irrigação da bananeira cv. FHIA-18 na região semiárida do Piauí. Irriga, v.18, n.4, p.756, 2013. https://doi.org/10.15809/irriga.2013v18n4p756. 
Garcia, G. de O.; Ferreira, P. A.; Vieira Miranda, G.; Lima Neves, J. C.; Bucker Moraes, W.; Batista dos Santos, D. Teores foliares dos macronutrientes catiônicos e suas relações com o sódio em plantas de milho sob estresse salino. Idesia, v.25, n.3, p.93-106, 2007. https://doi.org/10.4067/s0718-34292007000300010.

Instituto Brasileiro de Geografia e Estatística - IBGE. Levantamento Sistemático da produção Agrícola: pesquisa mensal de previsão e acompanhamento das safras agrícolas no ano civil. v.30, n.12. Rio de Janeiro: IBGE, 2017. 85p. https:// www.ibge.gov.br/estatisticas/economicas/agricultura-epecuaria/9201-levantamento-sistematico-da-producao-agricola. html ?edicao=20757\&t=downloads. 17 Feb. 2020.

Johns, G.; Mcconchie, D. Irrigation of bananas with secondary treated sewage effluent. I. Field evaluation of effect on plant nutrients and additional elements in leaf, pulp and soil. Australian Journal of Agricultural Research, v.45, n.7, p.1601-1617, 1994. https:// doi.org/10.1071/AR9941601.

Larcher, W. Ecofisiologia Vegetal. 3 ed. São Carlos: RIMA Artes e Textos, 2006. 532p.

Mantovani, J. R.; Ferreira, M. E.; Cruz, M. C. P. Da; Barbosa, J. C.; Freiria, A. C. Mineralização de carbono e de nitrogênio provenientes de composto de lixo urbano em Argissolo. Revista Brasileira de Ciência do Solo, v.30, n.4, p.677-684, 2006. https:// doi.org/10.1590/S0100-06832006000400008.

Martinez, H. E. P.; Carvalho, J. G. de; Souza, R. B. de. Diagnose Foliar. Recomendações para o uso de corretivos e fertilizantes em Minas Gerais. Viçosa: Comissão de Fertilidade do Solo do Estado de Minas Gerais - CFSEMG, 1999. p.143-166.

Montañés, L.; Heras, L.; Abadía, J.; Sanz, M. Plant analysis interpretation based on a new index: Deviation from optimum percentage (DOP). Journal of Plant Nutrition, v.16, n.7, p. 12891308, 1993. https://doi.org/10.1080/01904169309364613.

Palacios, M.; Haman, D.; Del-Nero, E.; Pardo, A.; Pavon, N. Banana production irrigated with treated effluent in the Canary Islands. Transactions of the ASAE, v.43, n.2, p.309-314, 2000. https://doi. org/10.13031/2013.2706.

Pegoraro, R. F.; Silva, I. R. Da; Novais, R. F.; Mendonça, E. de S.; Gebrim, F. de O.; MOREIRA, F. F. Fluxo difusivo e biodisponibilidade de zinco, cobre, ferro e manganês no solo: influência da calagem, textura do solo e resíduos vegetais. Revista Brasileira de Ciência do Solo, v.30, n.5, p.859-868, 2006. https://doi.org/10.1590/ S0100-06832006000500012.
Programa Brasileiro para a Modernização da Horticultura - PBMH; Produção Integrada de Frutas - PIF. Normas de classificação de banana. São Paulo: CEAGESP, 2006. 7p.

Sandri, D.; Rosa, R. de R. B. Atributos químicos do solo irrigado com efluente de esgoto tratado, fertirrigação convencional e água de poço. Irriga, v.22, n.1, p.18-33, 2017. https://doi.org/10.15809/ irriga.2017v22n1p18-33.

Santos, M. R. dos; Donato, S. L. R.; Lourenço, L. L.; Silva, T. S.; Coelho Filho, M. A. Irrigation management strategy for Prata-type banana. Revista Brasileira de Engenharia Agrícola e Ambiental, v. 20, n.9, p.817-822, 2016. https://doi.org/10.1590/18071929/agriambi.v20n9p817-822.

Secretaria de Estado de Agricultura, Pecuária e Abastecimento de Minas Gerais - SEAPA. Relatórios da Agricultura: banana. http:// www.agricultura.mg.gov.br/index.php/2014-09-23-01-07-23/ relatorios/agricultura. $30 \mathrm{Jul} .2020$.

Silva, E. N. da; Ribeiro, R. V.; Silva, S. L. F; Viégas, R. A.; Silveira, J. A. $G$. Salt stress induced damages on the photosynthesis of physic nut young plants. Scientia Agricola, v.68, n.1, p.62-68, 2011. https://doi.org/10.1590/S0103-90162011000100010.

Silva, J. T. A. da; Carvalho, J. G. de. Avaliação nutricional de bananeira "Prata Anã" (AAB), sob irrigação no semi-árido do norte de Minas Gerais, pelo método DRIS. Ciência e Agrotecnologia, v. 29, no 4, p. 731-739, 2005. https://doi.org/10.1590/S141370542005000400004.

Silva, J. T. A. da; Pacheco, D. D.; Costa, É. L. da. Atributos químicos e físicos de solos cultivados com bananeiras "Prata-Anã" (AAB), em três níveis de produtividade, no norte de Minas Gerais. Revista Brasileira de Fruticultura, v.29, n.1, p.102-106, 2007. https://doi.org/10.1590/S0100-29452007000100022.

Taiz, L.; Zeiger, E.; Mølle, I. M.; Murphy, A. Fisiologia e desenvolvimento vegetal. 6.ed. Porto Alegre: Artmed, 2017. $858 p$.

Tavares Filho, A. N.; Barros, M. de F. C.; Rolim, M. M.; Silva, Ê. F. de F. E. Incorporação de gesso para correção da salinidade e sodicidade de solos salino-sódicos. Revista Brasileira de Engenharia Agrícola e Ambiental, v.16, n.3, p.247-252, 2012. https://doi.org/10.1590/S1415-43662012000300002.

Veloso, C.; Muraoka, T.; Malavolta, E.; Carvalho, J. Influência do manganês sobre a nutrição mineral e crescimento da pimenteira do reino (Piper nigrum L.). Scientia Agricola, v.52, n.2, p.376-383, 1995. http://doi.org/10.1590/S0103-90161995000200028. 